\title{
Concentrations of organohalogen compounds and titres of antibodies to Epstein-Barr virus antigens and the risk for non-Hodgkin lymphoma
}

\author{
KARIN HARDELL ${ }^{1}$, MICHAEL CARLBERG $^{2}$, LENNART HARDELL $^{2}$, HELÉN BJÖRNFOTH $^{1}$, \\ INGRID ERICSON JOGSTEN $^{1}$, MIKAEL ERIKSSON ${ }^{3}$, BERT VAN BAVEL ${ }^{1}$ and GUNILLA LINDSTRÖM ${ }^{1}$ \\ ${ }^{1}$ MTM Research Centre, School of Science and Technology, Örebro University, SE-701 82 Örebro; ${ }^{2}$ Department of \\ Oncology, University Hospital, SE-701 85 Örebro; ${ }^{3}$ Department of Oncology, University Hospital, SE-221 85 Lund, Sweden
}

Received January 8, 2009; Accepted February 11, 2009

DOI: 10.3892/or_00000389

\begin{abstract}
Exposure to some pesticides and persistent organic pollutants (POPs) has been indicated to be a risk factor for non-Hodgkin's lymphoma (NHL). Epstein-Barr virus (EBV) has been associated with some subgroups of NHL. In a previous study we found an interaction between high concentrations of some POPs and titres of antibodies to EBV early antigen (EA IgG) in relation to NHL. In the present study we measured lipid adjusted plasma concentrations of 35 congeners of polychlorinated biphenyls (PCB), p, p'dichlorodiphenyldichloroethyelene (p,p'-DDE), hexachlorobenzene (HCB), seven subgroups of chlordanes (cisheptachlorepoxide, cis-chlordane, trans-chlordane, oxychlordane, MC6, trans-nonachlordane, cis-nonachlordane) and one polybrominated diphenylether (PBDE) congener (no. 47) in 99 cases with NHL and 99 population based controls. Odds ratios (OR) for NHL were estimated. Sum of PCBs $>$ median in the controls gave odds ratio (OR) $2.0,95 \%$ confidence interval (CI) 0.99-3.9. High sum of chlordanes yielded OR 2.3, 95\% CI 1.2-4.5. An interaction with EBV EA IgG was found. High sum of PCB gave OR 5.2, 95\% CI 1.9-14 in the group with EA IgG $>40$. Similarly HCB yielded OR 5.3, 95\% CI 1.9-15, pp'-DDE gave OR 3.3, 95\% CI 1.4-7.7 and sum of chlordanes yielded OR 6.8, 95\% CI 2.3-20, whereas no association was found with PBDE. In summary, this study confirmed an association between certain POPs and NHL with an interaction with titre of IgG antibody to EBV EA.
\end{abstract}

\section{Introduction}

Non-Hodgkin lymphoma (NHL) is a heterogeneous group of lymphoid malignancies. The modern classification system is

Correspondence to: Dr Lennart Hardell, Department of Oncology, University Hospital, SE-701 85 Örebro, Sweden E-mail: lennart.hardell@orebroll.se

Key words: non-Hodgkin lymphoma, polychlorinated biphenyls, persistent organic pollutants, Epstein-Barr virus, aetiology based on immunohistochemistry, cytogenetics and increasing knowledge of the clinical presentation and course of NHL. This has lead to the present classification system (1). It is therefore more adequate to discuss NHL as many different diseases, which share some features but also differ in several aspects.

The incidence of non-Hodgkin lymphoma (NHL) increased substantially during the second half of the 20th century in Sweden and in other Western countries with reliable cancer registries. However, during the last decade the increasing incidence has levelled off in many countries, such as Sweden, Denmark and USA (2). This change of the incidence may be explained by decreasing exposure to certain risk factors in the population.

The established risk factors for development of NHL include different immunosuppressive conditions, e.g., HIV, autoimmune diseases as Sjögren's syndrome and SLE, immunosuppressive drugs used after organ transplantation and some inherited conditions (3). However, these factors cannot explain the change of the incidence. Instead it is of interest that exposure to certain persistent organic pollutants (POPs), pesticides and organic solvents have been implicated to be of etiologic significance (4-11). An interaction between Epstein-Barr virus (EBV) and pesticides in the aetiology of NHL has been shown in some studies $(8,9,12-14)$.

It has been shown that Epstein-Barr virus (EBV) plays an essential role in the pathogenesis of lymphomas after organ transplantation (15). A relation between lymphoma and elevated EBV-titres has been reported in a cohort (16). EBV is a human herpes virus with a tropism for B-lymphocytes. The primary infection occurs during childhood and the majority of the population in the world has antibodies to EBV antigens. Normally, EBV-production is held back by active cellular and humoral immune mechanisms and a latent infection is established. Antibodies to EBV early antigen (EA), Viral Capsid antigen (VCA), and EBV nuclear antigen (EBNA) may be detected (17). In patients with immunodeficiency this balance may be disrupted and EBV-infected B-cells begin to proliferate (18).

Organochlorines have received increasing interest in the aetiology of NHL. These chemicals are lipophilic, persist in the environment, have long biologic half-lives and 
bioaccumulate in the food chain. Exposure to the general population has mainly occurred through food. Several organochlorines are immunosuppressive and an interaction with EBV in the aetiology of NHL has been indicated $(8,9,12)$.

Polychlorinated biphenyls (PCBs) have received special interest as risk factors for NHL, especially with EBV interaction $(8,12)$, but also in studies without analysis of antibodies to EBV antigens $(6,19,20)$. This topic has recently been further discussed by Engel et al $(21,22)$.

The production of PCB started in 1929 with increasing worldwide use in e.g. electrical equipment and buildings due to their chemical characteristics. Theoretically, 209 congeners are possible, but only about 130 are likely to occur in commercial products. Besides certain occupations humans are exposed mainly through the food chain, e.g. fish, meat and dairy products, and PCBs are mainly stored in the adipose tissue (23). The highest concentrations were found during the 1960s and 1970s, but have declined since then due to prohibition in Sweden in 1973 and cessation of production in USA in 1977 (24).

Also chlordanes have been indicated to be of aetiologic significance for NHL $(7,8,19,25)$. Technical chlordanes have been used in agriculture and for control of termites. The production started in the 1940 s and chlordanes were registered as insecticides in Sweden until 1969. They have been distributed throughout the biosphere and are still found in human adipose tissue.

Another organochlorine insecticide, that has been increasingly used since World War II, is dichlorodiphenyltrichloroethane (DDT). Its main metabolite p,p'-dichlorodiphenyldichloroethyelene ( $\left.\mathrm{p}, \mathrm{p}^{\prime}-\mathrm{DDE}\right)$ is a usual contaminant in human adipose tissue in the Western world. No convincing evidence of an association with NHL has been found, although an interaction with EBV EA IgG could not be ruled out in our previous study (8).

Also an interaction between hexachlorobenzene (HCB) and EBV EA IgG in the aetiology of NHL was indicated in our previous study (8). HCB is a fungicide that has been used in agriculture and has been found to be a contaminant in certain pesticides.

We have also found an interaction between adipose tissue concentrations of dioxins, dibenzofurans and EBV (9). However, these chemicals were not analysed now due to the high cost for such measurements.

The purpose of this study was to determine lipid-based plasma concentrations of the above discussed organochlorine compounds and also more recent environmental contaminants of concern, polybrominated diphenylethers (PBDE), in patients with NHL and population based controls. The concentrations of these substances were correlated to titres of antibodies to EBV EA. The responsible ethics committees approved the study.

\section{Materials and methods}

The study was population based and covered four health service regions in Sweden (Umeå, Örebro, Linköping, Lund) and data were collected during 2000-2002.

Cases. Physicians treating lymphoma and pathologists diagnosing the disease reported the cases. All consecutive
Table I. Histopathological types of 99 NHL cases.

\begin{tabular}{lr}
\hline Diagnosis & Number \\
\hline B-cell NHL & 90 \\
Lymfocytic lymphoma/ & \\
chronic lymphatic leukemia & 8 \\
Mantelcell lymphoma & 4 \\
Follicular lymphoma & 20 \\
Marginal zone lymphoma (MALT-lymphoma) & 1 \\
Diffuse large B-cell lymphoma & 39 \\
Burkitt lymphoma & 2 \\
Unspecified B-cell lymphoma & 16 \\
T/0-cell NHL & 8 \\
Unspecified malignant lymphoma & 1 \\
\hline
\end{tabular}

patients of both sexes aged 18-74 with newly diagnosed NHL were approached if their physician did not judge this as not suitable due to ethical reasons. All of the diagnostic pathological specimens were scrutinised by Swedish expert lymphoma reference pathologists. The pathologists also subdivided all NHL cases according to the WHO classification (1), to enable aetiological analyses also for the different diagnostic NHL entities.

Controls. From registries covering the whole Swedish population randomly chosen controls living in the same health service regions as the cases were recruited during several occasions within the study period. The controls were frequency matched in 10 years age and sex groups to mirror the age and sex distribution of the included cases, as to increase efficacy in the adjusted analyses. If they accepted to participate they were included as controls.

This study was part of a larger questionnaire based case-control investigation on risk factors for NHL including 995 cases of which 910 (91\%) participated. Of the 1108 enrolled controls 1016 (92\%) answered the questionnaire, as described in other publications $(11,26)$. Blood samples for this part of the study were obtained from a random subset of cases at the participating university hospitals and frequency matched control subjects. In total 203 cases and 254 controls were included. All samples got a unique idnumber that did not reveal if it was a case or a control. From this pool of specimens 100 cases were drawn at random and 100 controls fulfilling the matching criteria (sex, 10-year age group). Thus the present study encompassed in total 200 subjects.

Chemical analysis. Each sample $(2 \mathrm{ml})$ was extracted by solid phase extraction, using $200 \mathrm{mg}$ solid phase extraction (SPE) columns (ENV+). In addition, one laboratory blank sample and one reference sample of each set of 6 samples were analysed. The lipid content of each sample was determined enzymatic from a sub-sample. The samples were fortified with ${ }^{13} \mathrm{C}$-labelled internal $\mathrm{PCB}$ and $\mathrm{PBDE}$ and standards. Congener specific analyses and quantification of 
Table II. Concentrations of organohalogen compounds (ng/g lipid) in cases and controls.

\begin{tabular}{|c|c|c|c|c|c|c|}
\hline & Number & Mean & Median & Min & $\operatorname{Max}$ & $\mathrm{p}$-value \\
\hline \multicolumn{7}{|c|}{ Sum of PCBs* } \\
\hline Cases & 97 & 860 & 762 & 102 & 4222 & \multirow[t]{2}{*}{0.02} \\
\hline Controls & 98 & 672 & 646 & 122 & 2005 & \\
\hline \multicolumn{7}{|c|}{ Lower chlorinated $\mathrm{PCBs}{ }^{* *}$} \\
\hline Cases & 97 & 17 & 8.1 & 2.2 & 651 & \multirow[t]{2}{*}{0.45} \\
\hline Controls & 98 & 9.3 & 8.1 & 2.6 & 33 & \\
\hline \multicolumn{7}{|c|}{ Moderately chlorinated PCBs ${ }^{* * * *}$} \\
\hline Cases & 97 & 741 & 663 & 60 & 3748 & \multirow[t]{2}{*}{0.02} \\
\hline Controls & 98 & 587 & 559 & 101 & 1760 & \\
\hline \multicolumn{7}{|c|}{ Higher chlorinated PCBs ${ }^{* * * *}$} \\
\hline Cases & 97 & 20 & 16 & 1.0 & 143 & \multirow[t]{2}{*}{0.01} \\
\hline Controls & 98 & 15 & 13 & 1.6 & 45 & \\
\hline \multicolumn{7}{|c|}{ Immunotoxic PCBs ${ }^{* * * * *}$} \\
\hline Cases & 97 & 290 & 238 & 41 & 1297 & \multirow[t]{2}{*}{0.10} \\
\hline Controls & 98 & 234 & 226 & 47 & 748 & \\
\hline \multicolumn{7}{|l|}{$\mathrm{HCB}$} \\
\hline Cases & 99 & 31 & 26 & 0.42 & 140 & \multirow[t]{2}{*}{0.01} \\
\hline Controls & 99 & 27 & 24 & 0.34 & 215 & \\
\hline \multicolumn{7}{|l|}{$\mathrm{p}, \mathrm{p}^{\prime}-\mathrm{DDE}$} \\
\hline Cases & 99 & 486 & 307 & 5.4 & 2786 & \multirow[t]{2}{*}{0.11} \\
\hline Controls & 99 & 343 & 271 & 17 & 1414 & \\
\hline \multicolumn{7}{|c|}{ Cis-heptachlorepoxide } \\
\hline Cases & 99 & 1.0 & 0.45 & 0.01 & 8.4 & \multirow[t]{2}{*}{0.11} \\
\hline Controls & 99 & 0.75 & 0.31 & 0.005 & 4.3 & \\
\hline \multicolumn{7}{|c|}{ Cis-chlordane } \\
\hline Cases & 99 & 0.15 & 0.10 & 0.005 & 0.90 & \multirow[t]{2}{*}{0.50} \\
\hline Controls & 99 & 0.16 & 0.08 & 0.005 & 1.4 & \\
\hline \multicolumn{7}{|c|}{ Trans-chlordane } \\
\hline Cases & 99 & 0.14 & 0.12 & 0.005 & 0.73 & \multirow{2}{*}{0.66} \\
\hline Controls & 99 & 0.15 & 0.14 & 0.005 & 0.52 & \\
\hline \multicolumn{7}{|c|}{ Oxychlordane } \\
\hline Cases & 99 & 6.8 & 6.1 & 0.77 & 23 & 0.049 \\
\hline Controls & 99 & 5.8 & 4.8 & 0.50 & 20 & \\
\hline MC6 & & & & & & \\
\hline Cases & 99 & 3.8 & 3.1 & 0.39 & 33 & 0.053 \\
\hline Controls & 99 & 3.2 & 2.2 & 0.45 & 30 & \\
\hline Trans-nona & & & & & & \\
\hline Cases & 99 & 18 & 15 & 1.4 & 61 & 0.02 \\
\hline Controls & 99 & 14 & 11 & 2.0 & 61 & \\
\hline Cis-nonach & & & & & & \\
\hline Cases & 99 & 1.5 & 0.77 & 0.001 & 9.2 & 0.38 \\
\hline Controls & 99 & 1.2 & 0.65 & 0.0005 & 7.4 & \\
\hline Sum of chl & & & & & & \\
\hline Cases & 99 & 31 & 26 & 2.7 & 110 & 0.03 \\
\hline Controls & 99 & 25 & 19 & 3.4 & 101 & \\
\hline $\operatorname{PBDE}^{* * * * * * *}$ & & & & & & \\
\hline Cases & 99 & 2.8 & 1.5 & 0.20 & 79 & 0.30 \\
\hline Controls & 99 & 2.7 & 1.8 & 0.005 & 25 & \\
\hline
\end{tabular}

*The following PCB congeners were analysed: nos. 28, 52, 47/48, 74, 66, 101, 99/113, 110, 118, 114, 105, 153, 138, 128/167, 156, 157, 178, $182 / 187,174,172 / 192,180 / 193,170 / 190,189,202,199,194,206,209$. Two cases and one control were excluded from the calculation of the sum of PCBs since information about several congeners were lacking. ${ }^{* *} \mathrm{PCB}$ nos. 52, 66 and 74. ${ }^{* * *} \mathrm{PCB}$ nos. 99/113, 101, 105, 110, 118, 138, 153, 156, 170/190, 172/192, 178, 180/193, 182/187, 189. ${ }^{* * * *}$ PCB nos. 194 and 206. ${ }^{* * * * *}$ PCB nos. 66, 110, 105, 118, 74, 128/167, 156, 138, $170 / 190 .{ }^{* * * * * *}$ Congener no. 47 . Wilcoxon p-value is given. 
the analytes were performed by high-resolution gas chromatography coupled to high-resolution mass spectrometry (HRGC-HRMS), running in selective ion mode (SIM), using electron impact (EI) ionization. The two most abundant ions of the chlorine cluster of the molecular ion for each compound were measured, as well, as the ion for the ${ }^{13} \mathrm{C}$-labelled internal and recovery standards. A quantification standard mixture including all compounds in addition to the internal standard (IS) and recovery standard (RS) was used to calculate relative response factors (RRF). These RRFs were used to calculate the compound levels in the samples. All results were expressed in ng/g lipid (lipid adjusted).

The following PCB congeners were analysed nos. 28, 52, 47/48, 74, 66, 101, 99/113, 110, 118, 114, 105, 153, 138, $128 / 167,156,157,178,182 / 187,174,172 / 192,180 / 193$, 170/190, 189, 202, 199, 194, 206, 209 for all cases and controls. The database included also the PCB congeners nos. 141, 183, 177, 203/196, 195, but they were excluded from the sum of PCBs since results were not obtained for several study subjects. In addition two cases and one control were excluded from the calculation of the sum of PCBs since several other congeners were lacking. Regarding PBDE only one congener, no. 47, was analysed.

$E B V$ antigens. Indirect immunofluorescence was used for $\mathrm{IgG}$ antibodies to the virus capsid antigen (VCA) and the combined restricted and diffuse components of early antigens (EA R+D). The VCA IgG antibodies were end-point titrated in four-fold dilutions from $1 / 320$, while EA IgG was analysed in four-fold dilutions, allowing for detection of antibodies in dilution $\geq 1 / 20$ (titre $\geq 1 / 20$ ). Positive samples were endtitrated.

Statistical methods. Unconditional logistic regression analysis was performed using the Stata program (Stata/SE 8.2 for Windows; StataCorp, College Station, TX) for calculation of odds ratio (OR) and $95 \%$ confidence interval (CI). In the analyses adjustment was made for age as a continuous variable, sex and Body Mass Index (BMI) at the time of sampling. The median concentrations of antigens and organohalogenated compounds in the controls were used as cut-off values in the calculations of ORs and CIs since no biological relevant cut-off exists. The Stata program was also used for descriptive statistics and Wilcoxon rank sum tests for calculation of p-values.

In the analysis PCBs were grouped according to immunotoxic properties for the congeners nos. 66, 110, 105, $118,74,128 / 167,156,138$ and $170 / 190$ as suggested by Moysich et al (27). Sum of PCBs was grouped according to degree of chlorination; lower PCB nos. 52, 66, 74, moderately PCB nos. 99/113, 101, 105, 110, 118, 138, 153, $156,170 / 190,172 / 192,178,180 / 193,182 / 187,189$ and higher PCB nos. 194 and 206 as also suggested by Moysich et al (27).

\section{Results}

Due to technical reasons one sample, a case, could not be analysed. The respective control person was also excluded from further analysis. Thus, in total 99 cases and 99 controls were included in the analysis. The material included 58 male cases and controls and 41 female cases and controls. The mean age was for the 99 cases 55.9 years (median 57.0, range 19-75) and for the 99 controls 56.4 years (median 59.0, range 21-73). Men and women were of similar age without significant difference.

The different histopathological types of NHL are shown in Table I. Of the 99 cases 90 were B-cell and 8 T/0 cell and 1 unspecified NHL. The most common types were follicular B-cell lymphoma $(n=20)$ and diffuse large B-cell lymphoma $(n=39)$.

In Table II results are presented for the concentrations of organohalogen compounds in cases and controls. Significantly higher concentrations $(\mathrm{p}<0.05)$ were found in the cases for sum of PCBs, moderately chlorinated PCBs and higher chlorinated PCBs, HCB, oxychlordane, trans-nonachlordane, and sum of chlordanes. Regarding p,p'-DDE and PBDE no significant differences were found between cases and controls.

In Table III OR and $95 \%$ CI are presented for the different organohalogens. Regarding sum of PCBs OR 2.0, 95\% CI 0.99-3.9 was obtained. Significantly increased ORs were found for oxychlordane, trans-nonachlordane and MC 6. Sum of chlordanes yielded OR 2.3, 95\% CI 1.2-4.5. Sum of PCBs and especially higher chlorinated PCBs were significantly associated with follicular NHL but not with the diffuse large cell type. Regarding p,p'-DDE OR was significantly increased for diffuse large cell NHL. Sum of chlordanes yielded significantly increased OR both for follicular and diffuse large cell NHL.

The median titre of antibodies to EBV antigens was for VCA IgG 1280 (range 20-20480) for cases and 2560 (range 20-20480) for controls, $\mathrm{p}=0.86$. Regarding EA IgG median titre of 80 (range 20-10240) was obtained for cases and 40 (range 20-640) for controls, $\mathrm{p}=0.007$. Using median value for controls as cut-off VCA IgG gave OR 1.6, 95\% CI 0.8-3.0 and EA IgG OR 2.4, 95\% CI 1.3-4.3.

Results of analysis of interaction between titre of EA IgG and organohalogens are presented in Table IV. For all studied compounds except for PBDE an interaction was found with highest OR in the high concentration group and titre to EA IgG $>40$. Regarding grouping of PCBs in lower, moderately and higher chlorinated compounds significantly increased ORs were found for all groups in the category of EA IgG $>40$. For immunotoxic PCBs significantly increased risk was found in the high titre and high concentration group yielding OR 3.7, 95\% CI 1.4-9.6.

In Table $\mathrm{V}$ results are given for follicular lymphoma $(n=20)$. No significant associations were found but the results must be interpreted with caution due to low numbers. Highest OR was found for high sum of PCBs and different grouping of PCBs in the category with EA $\operatorname{IgG}>40$. Similar result was found for the sum of chlordanes and sum of different types, i.e. cis-chlordane, oxychlordane, MC6 and transnonachlordane. No clear association was found for HCB, p,p'-DDE and PBDE.

The same calculations for diffuse large cell NHL $(n=39)$ are presented in Table VI. An association was found with highest OR in the high category of all chemicals, except for trans-chlordane and PBDE, and $\mathrm{EA} \operatorname{IgG}>40$. 
Table III. Odds ratio (OR) and 95\% confidence interval (CI) for different organohalogen compounds and NHL, total ( $\mathrm{n}=99$ ), follicular $(n=20)$ and diffuse large cell $(n=39)$ B-cell lymphoma.

\begin{tabular}{|c|c|c|c|c|c|c|}
\hline & \multicolumn{2}{|c|}{ Total } & \multicolumn{2}{|c|}{ Follicular lymphoma } & \multicolumn{2}{|c|}{ Diffuse large cell lymphoma } \\
\hline & Cases/controls & $\mathrm{OR}, \mathrm{CI}$ & Cases/controls & $\mathrm{OR}, \mathrm{CI}$ & Cases/controls & $\mathrm{OR}, \mathrm{CI}$ \\
\hline Sum of PCBs & $59 / 49$ & $\begin{array}{c}2.0 \\
(0.99-3.9)\end{array}$ & $15 / 49$ & $\begin{array}{c}5.9 \\
(1.5-24)\end{array}$ & $20 / 49$ & $\begin{array}{c}1.6 \\
(0.6-4.0)\end{array}$ \\
\hline Lower chlorinated PCBs & $47 / 49$ & $\begin{array}{c}1.1 \\
(0.6-2.0)\end{array}$ & $13 / 49$ & $\begin{array}{c}2.8 \\
(0.9-9.0)\end{array}$ & $17 / 49$ & $\begin{array}{c}1.2 \\
(0.5-3.0)\end{array}$ \\
\hline Moderately chlorinated PCBs & $58 / 49$ & $\begin{array}{c}1.8 \\
(0.9-3.6)\end{array}$ & $15 / 49$ & $\begin{array}{c}5.8 \\
(1.5-23)\end{array}$ & $19 / 49$ & $\begin{array}{c}1.4 \\
(0.6-3.3)\end{array}$ \\
\hline Higher chlorinated PCBs & $63 / 49$ & $\begin{array}{c}1.7 \\
(0.8-3.4)\end{array}$ & $18 / 49$ & $\begin{array}{c}9.6 \\
(1.9-49)\end{array}$ & $22 / 49$ & $\begin{array}{c}1.3 \\
(0.5-3.4)\end{array}$ \\
\hline Immunotoxic PCBs & $54 / 49$ & $\begin{array}{c}1.5 \\
(0.8-3.0)\end{array}$ & $13 / 49$ & $\begin{array}{c}3.0 \\
(0.9-11)\end{array}$ & $19 / 49$ & $\begin{array}{c}1.4 \\
(0.6-3.3)\end{array}$ \\
\hline $\mathrm{HCB}$ & $56 / 49$ & $\begin{array}{c}1.4 \\
(0.8-2.5)\end{array}$ & $14 / 49$ & $\begin{array}{c}2.2 \\
(0.7-6.4)\end{array}$ & $20 / 49$ & $\begin{array}{c}1.2 \\
(0.5-2.6)\end{array}$ \\
\hline $\mathrm{p}, \mathrm{p}^{\prime}-\mathrm{DDE}$ & $53 / 49$ & $\begin{array}{c}1.5 \\
(0.8-2.9)\end{array}$ & $10 / 49$ & $\begin{array}{c}1.2 \\
(0.4-3.5)\end{array}$ & $24 / 49$ & $\begin{array}{c}2.8 \\
(1.1-6.7)\end{array}$ \\
\hline Cis-heptachlorepoxide & $54 / 49$ & $\begin{array}{c}1.3 \\
(0.7-2.4)\end{array}$ & $12 / 49$ & $\begin{array}{c}1.7 \\
(0.6-4.7)\end{array}$ & $21 / 49$ & $\begin{array}{c}1.4 \\
(0.6-3.0)\end{array}$ \\
\hline Cis-chlordane & $57 / 48$ & $\begin{array}{c}1.6 \\
(0.9-2.9)\end{array}$ & $15 / 48$ & $\begin{array}{c}3.3 \\
(1.1-10)\end{array}$ & $22 / 48$ & $\begin{array}{c}1.6 \\
(0.7-3.4)\end{array}$ \\
\hline Trans-chlordane & $42 / 49$ & $\begin{array}{c}0.8 \\
(0.4-1.4)\end{array}$ & $8 / 49$ & $\begin{array}{c}0.7 \\
(0.3-2.1)\end{array}$ & $18 / 49$ & $\begin{array}{c}0.9 \\
(0.4-2.0)\end{array}$ \\
\hline Oxychlordane & $60 / 49$ & $\begin{array}{c}2.1 \\
(1.1-4.0)\end{array}$ & $16 / 49$ & $\begin{array}{c}6.2 \\
(1.5-25)\end{array}$ & $22 / 49$ & $\begin{array}{c}2.0 \\
(0.8-4.8)\end{array}$ \\
\hline MC6 & $68 / 49$ & $\begin{array}{c}2.8 \\
(1.4-5.6)\end{array}$ & $16 / 49$ & $\begin{array}{c}5.0 \\
(1.4-19)\end{array}$ & $26 / 49$ & $\begin{array}{c}3.0 \\
(1.2-7.5)\end{array}$ \\
\hline Trans-nonachlordane & $62 / 49$ & $\begin{array}{c}2.4 \\
(1.2-5.0)\end{array}$ & $15 / 49$ & $\begin{array}{c}5.1 \\
(1.2-22)\end{array}$ & $24 / 49$ & $\begin{array}{c}3.0 \\
(1.1-8.2)\end{array}$ \\
\hline Cis-nonachlordane & $53 / 49$ & $\begin{array}{c}1.2 \\
(0.7-2.2)\end{array}$ & $12 / 49$ & $\begin{array}{c}1.5 \\
(0.5-4.4)\end{array}$ & $18 / 49$ & $\begin{array}{c}1.0 \\
(0.5-2.3)\end{array}$ \\
\hline Sum of chlordanes & $62 / 49$ & $\begin{array}{c}2.3 \\
(1.2-4.5)\end{array}$ & $15 / 49$ & $\begin{array}{c}3.9 \\
(1.1-14)\end{array}$ & $24 / 49$ & $\begin{array}{c}2.6 \\
(1.1-6.6)\end{array}$ \\
\hline PBDE & $39 / 49$ & $\begin{array}{c}0.7 \\
(0.4-1.2)\end{array}$ & $8 / 49$ & $\begin{array}{c}0.9 \\
(0.3-2.4)\end{array}$ & $16 / 49$ & $\begin{array}{c}0.8 \\
(0.4-1.7)\end{array}$ \\
\hline
\end{tabular}

Median concentration of the chemicals in the controls was used as cut-off. Numbers $>$ median are shown for cases and controls. Adjustment was made for age, sex and BMI.

\section{Discussion}

The study was population based. Cases were consecutively recruited from the participating clinics and pathology departments as soon as histopathological diagnosis was obtained. Thus it was possible to include the cases soon after diagnosis. Controls were selected at random from the
Swedish population registry whereby selection bias was avoided. The cases and controls were recruited during the same time period. Thus, bias of the results due to changes of the blood concentrations of the studied POPs over time was avoided (24). The blood samples were coded and during the chemical analysis it was not known if it was a case or a control. 
Table IV. Odds ratio (OR) and 95\% confidence interval (CI) for different organohalogen compounds and NHL (n=99) in relation to titre to Epstein-Barr virus early antigen (EA) IgG.

\begin{tabular}{|c|c|c|c|c|c|c|}
\hline \multirow[b]{2}{*}{ Exposure } & \multicolumn{3}{|c|}{$\mathrm{EA} \leq 40$} & \multicolumn{3}{|c|}{$\mathrm{EA}>40$} \\
\hline & Cases/controls & OR & $\mathrm{CI}$ & Cases/controls & OR & $\mathrm{CI}$ \\
\hline \multicolumn{7}{|l|}{ Sum of PCBs } \\
\hline$\leq$ median 646 & $14 / 25$ & $(1.0)$ & - & $24 / 24$ & 2.5 & $0.97-6.4$ \\
\hline$>$ median 646 & $20 / 29$ & 2.1 & $0.7-6.1$ & $39 / 20$ & 5.2 & $1.9-14$ \\
\hline \multicolumn{7}{|c|}{ Lower chlorinated PCBs } \\
\hline$\leq$ median 8.1 & $16 / 26$ & $(1.0)$ & $\cos ^{-}$ & $34 / 23$ & 3.1 & $\begin{array}{l}1.3-7.4 \\
1.2-7.8\end{array}$ \\
\hline$>$ median 8.1 & $18 / 28$ & 1.6 & & $29 / 21$ & 3.0 & \\
\hline \multicolumn{7}{|c|}{ Moderately chlorinated PCBs } \\
\hline$>$ median 559 & $20 / 29$ & 2.0 & $0.7-5.8$ & $38 / 20$ & 5.0 & $1.8-14$ \\
\hline \multicolumn{7}{|c|}{ Higher chlorinated PCBs } \\
\hline$\leq$ median 13 & $14 / 23$ & $(1.0)$ & - & $20 / 26$ & 1.5 & $0.6-3.8$ \\
\hline$>$ median 13 & $20 / 31$ & 1.1 & $0.4-3.0$ & $43 / 18$ & 3.9 & $1.4-10$ \\
\hline \multicolumn{7}{|c|}{ Immunotoxic PCBs } \\
\hline$\leq$ median 226 & $17 / 24$ & $(1.0)$ & - & $26 / 25$ & 1.9 & $0.8-4.6$ \\
\hline$>$ median 226 & $17 / 30$ & 1.2 & $0.4-3.4$ & $37 / 19$ & 3.7 & $1.4-9.6$ \\
\hline \multicolumn{7}{|l|}{$\mathrm{HCB}$} \\
\hline$\leq$ median 24 & $9 / 24$ & $(1.0)$ & - & $34 / 26$ & 3.9 & $1.5-10$ \\
\hline$>$ median 24 & $25 / 30$ & 2.5 & $0.9-6.7$ & $31 / 19$ & 5.3 & $1.9-15$ \\
\hline \multicolumn{7}{|l|}{ p,p'-DDE } \\
\hline$\leq$ median 271 & $20 / 28$ & $(1.0)$ & - & $26 / 22$ & 1.8 & $0.8-4.1$ \\
\hline$>$ median 271 & $14 / 26$ & 1.0 & $0.4-2.7$ & $39 / 23$ & 3.3 & 1.4-7.7 \\
\hline \multicolumn{7}{|c|}{ Cis-heptachlorepoxide } \\
\hline$\leq$ median 0.31 & $11 / 25$ & $(1.0)$ & - & $34 / 25$ & 3.5 & $1.4-8.8$ \\
\hline$>$ median 0.31 & $23 / 29$ & 2.1 & $0.8-5.5$ & $31 / 20$ & 4.2 & $1.6-11$ \\
\hline \multicolumn{7}{|l|}{ Cis-chlordane } \\
\hline$\leq$ median 0.08 & $12 / 25$ & $(1.0)$ & - & $30 / 26$ & 2.3 & $0.9-5.9$ \\
\hline$>$ median 0.08 & $22 / 29$ & 1.6 & $0.6-4.2$ & $35 / 19$ & 4.6 & $1.8-12$ \\
\hline \multicolumn{7}{|l|}{ Trans-chlordane } \\
\hline$\leq$ median 0.14 & $18 / 27$ & $(1.0)$ & - & $39 / 23$ & 2.6 & $1.1-5.9$ \\
\hline$>$ median 0.14 & $16 / 27$ & 0.9 & $0.4-2.2$ & $26 / 22$ & 1.9 & $0.8-4.5$ \\
\hline \multicolumn{7}{|l|}{ Oxychlordane } \\
\hline$\leq$ median 4.8 & $13 / 23$ & $(1.0)$ & - & $26 / 27$ & 2.0 & $0.8-5.1$ \\
\hline$>$ median 4.8 & $21 / 31$ & 1.7 & $0.6-4.9$ & $39 / 18$ & 6.3 & $2.2-18$ \\
\hline \multicolumn{7}{|l|}{ MC6 } \\
\hline$\leq$ median 2.2 & $12 / 25$ & $(1.0)$ & - & $19 / 25$ & 2.0 & $0.7-5.4$ \\
\hline$>$ median 2.2 & $22 / 29$ & 2.4 & $0.8-6.7$ & $46 / 20$ & 7.0 & $2.5-19$ \\
\hline \multicolumn{7}{|c|}{ Trans-nonachlordane } \\
\hline$\leq$ median 11 & $13 / 25$ & $(1.0)$ & - & $24 / 25$ & 2.1 & $0.8-5.5$ \\
\hline$>$ median 11 & $21 / 29$ & 2.2 & $0.8-6.5$ & $41 / 20$ & 7.2 & $2.4-21$ \\
\hline \multicolumn{7}{|l|}{ Cis-nonachlordane } \\
\hline$\leq$ median 0.65 & $11 / 24$ & $(1.0)$ & - & $35 / 26$ & 3.4 & $1.3-8.7$ \\
\hline$>$ median 0.65 & $23 / 30$ & 2.0 & $0.7-5.5$ & $30 / 19$ & 4.2 & $1.5-12$ \\
\hline \multicolumn{7}{|l|}{ Sum of chlordanes } \\
\hline$\leq$ median 19 & $13 / 23$ & $(1.0)$ & - & $24 / 27$ & 1.8 & $0.7-4.7$ \\
\hline$>$ median 19 & $21 / 31$ & 1.8 & $0.6-5.1$ & $41 / 18$ & 6.8 & $2.3-20$ \\
\hline \multicolumn{7}{|l|}{ PBDE } \\
\hline$\leq$ median 1.8 & $17 / 24$ & $(1.0)$ & - & $43 / 26$ & 2.7 & $1.2-6.2$ \\
\hline$>$ median 1.8 & $17 / 30$ & 0.9 & $0.4-2.3$ & $22 / 19$ & 1.8 & $0.7-4.5$ \\
\hline
\end{tabular}

As cut-off the median concentration of the chemicals and titre to EA in the controls was used. Numbers (expressed in ng/g lipid) are shown for cases and controls. Adjustment was made for age, sex and BMI. 
Table V. Odds ratio (OR) and 95\% confidence interval (CI) for different organohalogen compounds and follicular NHL $(\mathrm{n}=20)$ in relation to titre to Epstein-Barr virus early antigen $(\mathrm{EA}) \mathrm{IgG}$.

\begin{tabular}{|c|c|c|c|c|c|c|}
\hline \multirow[b]{2}{*}{ Exposure } & \multicolumn{3}{|c|}{$\mathrm{EA} \leq 40$} & \multicolumn{3}{|c|}{$\mathrm{EA}>40$} \\
\hline & Cases/controls & OR & $\mathrm{CI}$ & Cases/controls & OR & $\mathrm{CI}$ \\
\hline \multicolumn{7}{|l|}{ Sum of PCBs } \\
\hline$\leq$ median 646 & $4 / 25$ & $(1.0)$ & - & $1 / 24$ & 0.3 & $0.03-3.5$ \\
\hline$>$ median 646 & $7 / 29$ & 3.5 & $0.6-21$ & $8 / 20$ & 4.2 & $0.9-21$ \\
\hline \multicolumn{7}{|c|}{ Lower chlorinated PCBs } \\
\hline$>$ median 8.1 & $6 / 28$ & 1.7 & $0.4-7.8$ & $7 / 21$ & 2.6 & $0.6-11$ \\
\hline \multicolumn{7}{|c|}{ Moderately chlorinated PCBs } \\
\hline$>$ median 559 & $7 / 29$ & 3.4 & $0.6-20$ & $8 / 20$ & 4.2 & $0.8-20$ \\
\hline \multicolumn{7}{|c|}{ Higher chlorinated PCBs } \\
\hline$\leq$ median 13 & $2 / 23$ & $(1.0)$ & - & $0 / 26$ & - & - \\
\hline$>$ median 13 & $9 / 31$ & 3.2 & $0.5-19$ & $9 / 18$ & 5.1 & $0.9-30$ \\
\hline \multicolumn{7}{|c|}{ Immunotoxic PCBs } \\
\hline$\leq$ median 226 & $6 / 24$ & $(1.0)$ & - & $1 / 25$ & 0.2 & $0.02-1.7$ \\
\hline$>$ median 226 & $5 / 30$ & 1.0 & $0.2-5.3$ & $8 / 19$ & 2.2 & $0.5-8.9$ \\
\hline \multicolumn{7}{|l|}{$\mathrm{HCB}$} \\
\hline$\leq$ median 24 & $2 / 24$ & $(1.0)$ & - & $4 / 26$ & 1.8 & $0.3-11$ \\
\hline$>$ median 24 & $9 / 30$ & 3.2 & $0.6-17$ & $5 / 19$ & 2.8 & $0.4-18$ \\
\hline \multicolumn{7}{|l|}{ p,p'-DDE } \\
\hline$\leq$ median 271 & $8 / 28$ & $(1.0)$ & - & $2 / 22$ & 0.3 & $0.1-1.7$ \\
\hline$>$ median 271 & $3 / 26$ & 0.5 & $0.1-2.2$ & $7 / 23$ & 1.2 & $0.3-4.3$ \\
\hline \multicolumn{7}{|c|}{ Cis-heptachlorepoxide } \\
\hline$\leq$ median 0.31 & $3 / 25$ & $(1.0)$ & - & $5 / 25$ & 2.3 & $0.4-12$ \\
\hline$>$ median 0.31 & $8 / 29$ & 3.4 & $0.7-16$ & $4 / 20$ & 1.8 & $0.3-10$ \\
\hline \multicolumn{7}{|l|}{ Cis-chlordane } \\
\hline$\leq$ median 0.08 & $2 / 25$ & $(1.0)$ & - & $3 / 26$ & 1.4 & $0.2-9.5$ \\
\hline$>$ median 0.08 & $9 / 29$ & 3.9 & $0.7-21$ & $6 / 19$ & 4.2 & $0.7-25$ \\
\hline \multicolumn{7}{|l|}{ Trans-chlordane } \\
\hline$\leq$ median 0.14 & $6 / 27$ & $(1.0)$ & - & $6 / 23$ & 1.2 & $0.3-4.5$ \\
\hline$>$ median 0.14 & $5 / 27$ & 1.0 & $0.2-3.9$ & $3 / 22$ & 0.7 & $0.1-3.2$ \\
\hline \multicolumn{7}{|l|}{ Oxychlordane } \\
\hline$\leq$ median 4.8 & $3 / 23$ & $(1.0)$ & - & $1 / 27$ & 0.3 & $0.03-3.6$ \\
\hline$>$ median 4.8 & $8 / 31$ & 2.9 & $0.5-16$ & $8 / 18$ & 5.0 & $0.9-28$ \\
\hline \multicolumn{7}{|l|}{ MC6 } \\
\hline$\leq$ median 2.2 & $3 / 25$ & $(1.0)$ & - & $1 / 25$ & 0.3 & $0.03-3.5$ \\
\hline$>$ median 2.2 & $8 / 29$ & 2.5 & $0.5-13$ & $8 / 20$ & 4.0 & $0.8-20$ \\
\hline \multicolumn{7}{|c|}{ Trans-nonachlordane } \\
\hline$\leq$ median 11 & $3 / 25$ & $(1.0)$ & - & $2 / 25$ & 0.7 & $0.1-5.2$ \\
\hline$>$ median 11 & $8 / 29$ & 3.7 & $0.6-25$ & $7 / 20$ & 5.1 & $0.8-33$ \\
\hline \multicolumn{7}{|l|}{ Cis-nonachlordane } \\
\hline$\leq$ median 0.65 & $3 / 24$ & $(1.0)$ & - & $5 / 26$ & 1.8 & $0.4-8.7$ \\
\hline$>$ median 0.65 & $8 / 30$ & 2.5 & $0.5-11$ & $4 / 19$ & 1.7 & $0.3-9.2$ \\
\hline \multicolumn{7}{|l|}{ Sum of chlordanes } \\
\hline$\leq$ median 19 & $3 / 23$ & $(1.0)$ & - & $2 / 27$ & 0.6 & $0.1-4.2$ \\
\hline$>$ median 19 & $8 / 31$ & 2.4 & $0.5-13$ & $7 / 18$ & 4.0 & $0.7-22$ \\
\hline \multicolumn{7}{|l|}{ PBDE } \\
\hline$\leq$ median 1.8 & $7 / 24$ & $(1.0)$ & - & $5 / 26$ & 0.7 & $0.2-2.7$ \\
\hline$>$ median 1.8 & $4 / 30$ & 0.6 & $0.2-2.5$ & $4 / 19$ & 0.9 & $0.2-3.8$ \\
\hline
\end{tabular}

As cut-off the median concentration of the chemicals and titre to EA in the controls was used. Numbers (expressed in ng/g lipid) are shown for cases and controls. Adjustment was made for age, sex and BMI. 
Table VI. Odds ratio (OR) and 95\% confidence interval (CI) for different organohalogen compounds and diffuse large cell NHL $(n=39)$ in relation to titre to Epstein-Barr virus early antigen (EA) IgG.

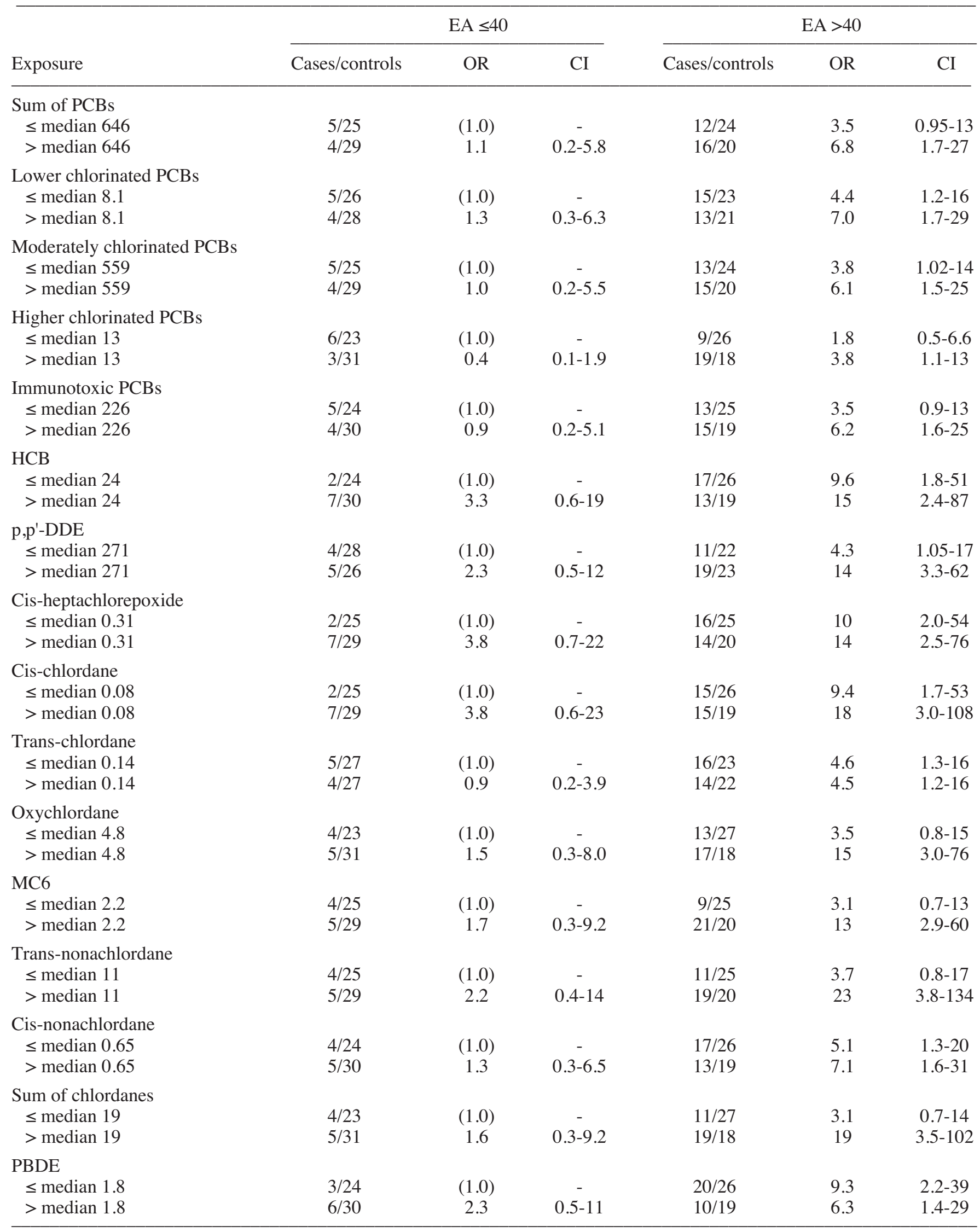

As cut-off the median concentration of the chemicals and titre to EA in the controls was used. Numbers (expressed in ng/g lipid) are shown for cases and controls. Adjustment was made for age, sex and BMI. 
All concentrations of POPs were lipid based since these chemicals are fat-soluble. Changes of body weight might influence the results and we have reported high concentrations of POPs in a cancer patient with cachexia (28). To avoid a treatment related change of BMI all blood samples were drawn before any treatment of the case. The mean value of BMI was for the cases 24.6 and for the controls 26.5 $(\mathrm{p}=0.0007)$ so all results were adjusted for BMI at the time of blood sampling.

In this study we found significantly increased concentrations of the sum of PCBs, HCB and sum of chlordanes in the cases. An interaction between elevated EA IgG and these chemicals was found. Furthermore, in the high concentration group of p,p'-DDE and high titre to EA IgG OR 3.3, 95\% CI 1.4-7.7 was obtained. When analysing the chemicals only without considering titre of EA IgG lower ORs were obtained. This suggests an interaction between these chemicals and EBV. These results are similar to our previous studies on this topic (6-8) and as also found in other studies $(12,19,20)$.

We analysed PCBs in the groups according to chlorination as suggested by De Roos et al (19). We found an interaction between EA IgG for moderate and high-chlorinated PCBs. Also De Roos et al (19) found highest ORs in these groups in highest quartile but data on titres of antibodies to EBV were not analysed in that study. We did not find an interaction between EA IgG and low-chlorinated PCBs and also De Roos et al (19) had no clear association in the group with low-chlorinated PCBs.

Low numbers hampered division of the material according to subtypes of NHL. Thus, only eight cases had T-cell NHL. Clearly we found highest OR in the group of cases with EA IgG $>40$ and sum of PCBs and HCB $>$ median in the controls, whereas the same tendency was not found for the other studied chemicals (data not shown). However, these results may be due to random variation since the calculations were based on low numbers and must thus be interpreted with caution.

Regarding follicular and diffuse large B-cell lymphoma some interesting findings were noted. An association between different POPs and follicular lymphoma was found, significantly so for sum of PCBs, moderately and higher chlorinated PCBs. Sum of chlordanes was associated both with follicular and large B-cell lymphoma. On the contrary, in general a more clear association was found for the diffuse large B-cell type regarding an interaction between the organohalogen compound and titres of EA IgG. The only exception was for PBDE. Regarding follicular lymphoma a tendency was found for sum of PCBs and chlordanes but not for HCB, pp'-DDE and PBDE. These results indicate that interaction between certain POPs and EA IgG differs between follicular and large B-cell lymphoma. It should however be noted that the results especially for follicular lymphoma were based on low numbers and should be interpreted with caution.

An interaction between certain POPs and EBV is of interest in the aetiology of NHL. EBV has been associated with certain types of NHL such as Burkitt lymphoma and lymphomas in immunologically compromised or HIVinfected subjects (29). Immunosuppression is a risk factor for
NHL and exposure to organochlorines has been reported to compromise the immune system in humans (30). Immunosuppression may lead to loss of cell-mediated immune control of reactivated EBV and give clonal expansion of cells.

Of special interest are studies on chromosomal translocation in NHL and exposure to pesticides. The risk of $\mathrm{t}(14 ; 18)$-positive NHL has been indicated to be increased in subjects exposed to herbicides, insecticides and fungicides $(31,32)$. No such data exist for POPs and NHL. However, these results indicate that defining subsets of NHL according to $t(14 ; 18)$ status would be of value for further studies regarding the association between POPs and NHL.

In summary this study showed an association between certain organochlorine compounds and NHL with an interaction with titre of IgG antibody to EBV EA.

\section{Acknowledgements}

This study was supported by grant no. 2001-0224 from FAS, Cancer- och Allergifonden, Cancerhjälpen, Örebro University Hospital Cancer Fund and Lions Research Foundation. Ms. Iréne Larsson participated in the data collection and Matz Eriksson performed interviews. Analysis of EBV antibodies was performed at The Swedish Institute for Infectious Disease Control (SMI), Solna, Sweden.

\section{References}

1. Jaffe ES, Harris NL, Stein H and Vardiman JW: World Health Organization classification of Tumours. Pathology \& Genetics. Tumours of Haematopoetic and Lymphoid Tissues. IARC, Lyon 2001.

2. Hardell L and Eriksson M: Is the decline of the increasing incidence of non-Hodgkin lymphoma in Sweden and other countries a result of cancer preventive measures? Environ Health Perspect 111: 1704-1706, 2003.

3. Hardell L and Axelson O: Environmental and occupational aspects on the etiology of non-Hodgkin's lymphoma. Oncol Res 10: 1-5, 1998.

4. Hardell L, Eriksson M, Lenner P and Lundgren E: Malignant lymphoma and exposure to chemicals, especially organic solvents, chlorophenols and phenoxy acids; A case-control study. Br J Cancer 43: 169-176, 1981.

5. Hardell L and Eriksson M: A case-control study of nonHodgkin lymphoma and exposure to pesticides. Cancer 85: $1353-1360,1999$

6. Hardell L, van Bavel B and Lindström G: Higher concentrations of specific polychlorinated biphenyl congeners in adipose tissue from non-Hodgkin's lymphoma patients compared with controls without a malignant disease. Int J Oncol 9: 601-608, 1998.

7. Hardell L, Liljegren G, Lindström G, et al: Increased concentrations of chlordane in adipose tissue from non-Hodgkin's lymphoma patients compared with controls without a malignant disease. Int J Oncol 9: 1139-1142, 1996.

8. Hardell L, Eriksson M, Lindström G, et al: Case-control study on concentrations of organohalogen compounds and titres of antibodies to Epstein-Barr virus antigens in the etiology of nonHodgkin lymphoma. Leuk Lymphoma 42: 619-629, 2001.

9. Hardell L, Lindström, G, van Bavel B, et al: Adipose tissue concentrations of dioxins and dibenzofurans, titers of antibodies to Epstein-Barr virus early antigen and the risk for non-Hodgkin lymphoma. Environ Res 87: 99-107, 2001.

10. Hardell L, Eriksson M, Axelson O and Flesch-Janys D: Epidemiological studies on cancer and exposure to dioxins and related compounds. In: Dioxins and Health. Schecter A and Gasiewicz T (eds). John Wiley \& Sons, Inc., Hoboken, NJ, pp 729-764, 2003.

11. Eriksson M, Hardell L, Carlberg M and Åkerman M: Pesticide exposure as risk factor for non-Hodgkin lymphoma including histopathological subgroup analysis. Int J Cancer 123: 1657-1663, 2008 . 
12. Rothman N, Cantor KP, Blair A, et al: A nested case-control study on non-Hodgkin lymphoma and serum organochlorine residues. Lancet 350: 240-244, 1997.

13. Nordström M, Hardell L, Linde A and Schloss L: Elevated antibody levels to Epstein-Barr virus antigens in patients with hairy cell leukaemia compared to controls in relation to exposure to pesticides, organic solvents, animals and exhausts. Oncol Res 11: 539-544, 1999.

14. Nordström M, Hardell L, Lindström G, Wingfors H, Hardell K and Linde A: Concentrations of organochlorines related to titres to Epstein-Barr virus Early Antigen (EA) IgG as risk factors for hairy cell leukaemia. Environ Health Perspect 108 : 441-445, 2000

15. Patton DF, Wilkowski CW, Hanson CA, et al: Epstein-Barr virus-determined clonality in posttransplant lymphoproliferative disease. Transplantation 49: 1080-10844, 1990.

16. Lehtinen T, Lumio J, Dillner J, et al: Increased risk of malignant lymphoma indicated by elevated Epstein-Barr virus antibodies a prospective study. Cancer Causes Control 4: 187-193, 1993.

17. Linde A: Diagnosis and pathogenesis of infectious mononucleosis and other Epstein Barr virus-associated diseases. Rev Med Microbiol 1: 300-312, 1992.

18. Potter M: Pathogenetic mechanisms in B-cell non-Hodgkin's lymphomas in humans. Cancer Res 52: S5522-S5528, 1992.

19. De Roos AJ, Hartge P, Lubin JH, et al: Persistent organochlorine chemicals in plasma and risk of non-Hodgkin's lymphoma. Cancer Res 65: 11214-11226, 2005.

20. Colt JS, Severson RK, Lubin J, et al: Organochlorines in carpet dust and non-Hodgkin lymphoma. Epidemiology 16: 516-525, 2005

21. Engel LS, Lan O and Rothman N: Polychlorinated biphenyls and non-Hodgkin lymphoma. Cancer Epidemiol Biomarkers Prev 16: 373-376, 2007.

22. Engel LS, Laden F, Andersen A, et al: Polychlorinated biphenyl levels in peripheral blood and non-Hodgkin's lymphoma: a report from three cohorts. Cancer Res 67: 5545-5552, 2007.
23. Dobson S and van Esch GJ: Polychlorinated Biphenyls and Terphenyls (2nd edition). In Environmental Health Criteria, Vol 140. World Health Organization, Geneva, 1993.

24. Norén K and Meironyté D: Certain organochlorine and organobromine contaminants in Swedish human milk in perspective of past 20-30 years. Chemosphere 40: 1111-1123, 2000.

25. Quintana PJ, Delfino RJ, Korrick S, et al: Adipose tissue levels of organochlorine pesticides and polychlorinated biphenyls and risk of non-Hodgkin's lymphoma. Environ Health Perspect 112: 854-861, 2004.

26. Hardell L, Eriksson M, Carlberg M, Sundström C and Hansson Mild K: Use of cellular and cordless telephones and the risk for non-Hodgkin's lymphoma. Int Arch Environ Health 78: 625-632, 2005.

27. Moysich KB, Mendola P, Schisterman EF, et al: An evaluation of proposed frameworks for grouping polychlorinated biphenyl (PCB) congener data into meaningful analytic units. Am J Ind Med 35: 223-231, 1999.

28. Hardell L, Lindström G, van Bavel B, Wedrén H and Melgaard B High concentrations of organochlorines in a patient with kidney cancer. Med Chem 2: 607-610, 2006.

29. Okano M, Thiele GM, Davis JR, Grierson HL and Purtilo DT: Epstein-Barr virus and human diseases: recent advances in diagnosis. Clin Microbiol Rev 1: 300-312, 1998.

30. McConnachie PR and Zahalsky AC: Immune alternations in humans exposed to the termicide technical chlordane. Arch Environ Health 47: 295-301, 1992.

31. Schroeder JC, Olshan AF, Baric R, et al: Agricultural risk factors for $\mathrm{t}(14 ; 18)$ subtypes of non-Hodgkin's lymphoma. Epidemiology 12: 701-709, 2001.

32. Chiu BC, Dave BJ, Blair A, Gapstur SM, Zahm SH and Weisenburger DD: Agricultural pesticide use and risk of $\mathrm{t}(14 ; 18)$-defined subtypes of non-Hodgkin lymphoma. Blood 108: 1363-1369, 2006. 